\title{
Paleoclimate of Interglacial Marine Isotope Stage 11 (MIS 11) from Strata in the Japanese Islands
}

\begin{abstract}
Fujio Masuda*

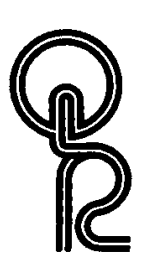

Paleoclimate of interglacial Marine Isotope Stage 11 (MIS 11), about $400 \mathrm{ky}$ ago was estimated using data from shallow-marine to terrestrial strata of the Japanese Islands. The reason of the estimation comes from that the paleoclimate gives analogs for the future climate, because the conditions of Milankovitch forcing of MIS 11 are similar to those of modern Holocene. The results show the MIS 11 of the Japanese Islands was warmer, with a longer interval of highstand, and higher sea levels than the other interglacials. Further investigation for the strata of MIS 11 of the Japanese Island is needed and will give us important information about our future climate.
\end{abstract}

Keywords : interglacial, Jizodo Formation, MIS 11, paleoclimate, the Japanese Islands, the 9th Marie Clay Bed (Ma 9)

\section{Introduction}

Over the last 700,000 years, the Earth's climate has oscillated between cold glacial and warm interglacial intervals, mostly in cycles with a period of about $100 \mathrm{ky}$. The oscillation also includes shorter cycles of $41 \mathrm{ky}, 23 \mathrm{ky}$ and $18 \mathrm{ky}$. We believe that these climatic cycles, known as "Milankovitch cycles", are the result of astronomically induced changes in the distribution of solar energy reaching the Earth (Imbrie et al., 1984 ; Berger et al., 1996). The climatic changes due to Milankovitch cycles, known as, "Milankovitch forcing", are the most important determining factor for climate over the past $700 \mathrm{ky}$. We are now in a warm interval, the Holocene interglacial of the Marine Isotope Stage 1 (MIS 1). This warm interval has lasted for about $10 \mathrm{ky}$ and is characterized by minimum eccentricity of the Earth's orbit and low amplitude of the precessional cycle. These Milankovitch forcing conditions are similar to those of Marine Isotope Stage 11 (MIS 11), about $400 \mathrm{ky}$ ago (Berger and Loutre, 2003 ; Berger et al., 2003 ;
Droxler et al., 2003). Finding and studying analogs from the MIS 11 interglacial can provide a powerful tool to improve our understanding of our present-day climate and how it might change in the future.

According to Droxler et al. (2003), MIS 11 was an unusual and perhaps unique interglacial interval. It exhibited warm interglacial climatic conditions for a period of at least $30 \mathrm{ky}$, more than twice as long as the modern interglacial stage (MIS 1) ; it was characterized by a warm climatic conditions that were probably warmer than any conditions observed since $2.2 \mathrm{Ma}$; and melting of the Greenland and West Antarctic ice sheets contributed to sea levels that were most likely 13 to $20 \mathrm{~m}$ higher than current sea levels. Variation of temperature and $\mathrm{CO}_{2}$ content in the atmosphere during MIS 11 and MIS 1 (Broecker and Stocker, 2006) show a strong correlation. This facts and evidence from analysis of Antarctic ice cores, suggest that the current warm interglacial may continue for some time.

In this study, I used data from shallow-marine

Received December 6, 2006. Accepted January 25, 2007.

* Department of Environmental Systems Science, Faculty of Technology, Doshisha University. 1-3 Tataratoya, Kyotanabe, Kyoto, 610-0321, Japan. E-mail : fmasuda@mail.doshisha.ac.jp 
to terrestrial strata of the Japanese Islands to show that the climate of MIS 11 was different from that of other interglacials. In particular, MIS 11 was warmer, with a longer duration, and higher sea levels.

\section{Strata of MIS 11}

Strata formed by the glacio-eustatic sea level changes of the middle to late Quaternary are present on the Japanese Islands. Plio-Pleistocene to Holocene sequences of several hundred meters thickness are well developed, especially in the Boso Peninsula and Osaka Bay areas of central Japan. Both of these areas were inundated at the interglacial highstand and emergent at the glacial lowstand. These sequences therefore can be clearly correlated with marine oxygen isotope curves from deep sea cores (Fig. 1, Masuda, 1997a ; Masuda and Ito, 1999).

Strata correlated with MIS 11 include the Jizodo Formation of the Shimosa Group on the Boso Peninsula (Machida et al., 1980), and the 9th Marine Clay Bed (so-called "Ma 9") of the Osaka Group in Osaka Bay area (Yokoyama et al., 1980). The Jizodo Formation is a forearc basin deposit and the 9th Marine Clay Bed is an intra-arc basin deposit.

In this paper, I discuss mainly paleoclimatic information obtained from the Jizodo Formation and 9th Marine Clay Bed (Ma 9), but also briefly discuss MIS 11 deposits from other areas.

\section{The Jizodo Formation of the Shimosa Group}

The Jizodo Formation, a sequence correlated with MIS 11, is consistently thicker than its overlying and underlying sequences. In ascending order, it is composed of a sequence of thin gravelly sand and mud, which together represent lowstand fluvial deposits, transgressive estuary bay-floor mud, and thicker sand of highstand delta or shoreface deposits. The Jizodo Formation in Kisarazu area is $74-85 \mathrm{~m}$ thick, which is thicker than other formations deposited during the interglacial that were reported to be $15-65 \mathrm{~m}$ thick by Tokuhashi and Kondo (1989), and Okazaki (1996). The thicker sequence, however, cannot be solely attributed to a longer interglacial interval because other factors, such as tectonic activity, eustasy, and sediment sup- ply (flux), also contribute to sequence thickness. Sea level during MIS 11 may have been higher than that of the modern intergalacial (MIS 1). The height of foresets in fluvio-deltaic deposits in the Jizodo Formation is about $23 \mathrm{~m}$. The height of these structures, which are formed by delta progradation, shows the paleodepth of the delta front at the time of their deposition. Their height in the Jizodo Formation is greater than in modern deltas in these area (the Koito River delta, $12-18 \mathrm{~m}$; the Obitsu River delta, $8-16 \mathrm{~m}$ ), and greater than the deltaic succession of MIS 7, reported as about 15-18 (?) m by Okazaki et al. (2000). This suggests that the sea level during MIS 11 was 5-7 $\mathrm{m}$ higher than those of MIS 7 and the present-day (MIS 1).

The Jizodo Formation contains abundant shallow-marine fossil shells. A warm- and deepwater shell assemblage, including Glycymeris pilsbryi, Cryptopecten vesiculosus, and Nemocardium samarangae of the "Jizodo fossil bed", was reported from the middle of the formation (Aoki and Baba, 1971, 1973 ; Tokuhashi and Kondo, 1989). This assemblage indicates water depths from 50-60 to 100-120 m (O'Hara, 1973 ; Kondo, 1989 ; Okazaki, 1996). No other horizon in the Shimosa Group contains such a deep-water assemblage, with the exception of a thin bed within MIS 9 that also includes some shells from a shallow-water assemblage.

Relatively high paleotemperatures and paleosalinities were calculated by Masuda (1977b, c) based on analyses of oxygen and carbon isotopes and strontium content from the fossil molluscan shells of the upper part of the Jizodo Formation. These results strongly suggest that sea level during MIS 11 in this area was higher, and sea temperature was warmer, than in other interglacial periods.

Although the Jizodo Formation was deposited during the MIS 11 interglacial, it includes a few micro-sequences that show small changes of relative sea level (Kamataki and Kondo, 1997 ; Nishikawa and Ito, 1997). There are several possible explanations for these micro-sequences, and their existence is corroborated by some small fluctuations of relative sea level shown in the curves of ice-core record. 


\section{The 9th Marine Clay Bed of the Osaka Group}

The 9th Marine Clay Bed (Ma 9), which is correlated to MIS 11 is within the fill deposits of an active subsiding basin represented by the Osaka Group (Itihara, 1993). The fill deposits are characterized by alternations of coarse-grained nonmarine fluvial deposits and marine bay-floor muddy deposits (Ikebe et al., 1970). There are 15 layers of marine bay-floor mud intercalated in the upper Osaka Group and the 9th Marine Clay Bed is one of them (Marine Clay, No. 9 in Fig. 1).

The 9th Marine Clay Bed is a homogenous bed with $26-43 \mathrm{~m}$ thick. It is thicker than the other marine bay-floor mud layers in the sequence, and is easily traced throughout the basin (Furutani, 1993). It is also thicker than the interglacial Marine Clay Beds of other marine isotope stage sequences (Osakawan-KibanjohoKenkyu-Kyogikai, 2002). For example, the marine clay of MIS 5 is $12-30 \mathrm{~m}$ thick. The thicker bay-floor mud may be indicative of a longer duration of deposition, and hence a longer warm interglacial period for MIS 11.

The 9th Marine Clay Bed is more widely distributed than other marine clays, such as the 7 th, 8th, 10th, 11th, 12th and 13th. Its presence has been reported in the adjacent Kyoto Basin, about $20-30 \mathrm{~km}$ upper stream area (KansaiJibanjohokatuyo-Kyogikai, 2002). However, this correlation needs to be reinvestigated and confirmed.

On the basis of pollen analysis, the interglacial period of the 9th Marine Clay Bed had the warmest climate of all interglacial periods in the last $700 \mathrm{ky}$ (Furutani, 1991 ; Yoshikawa, 1999). The Syzygium flora assemblage, which requires a warm environment, is included in this hori-

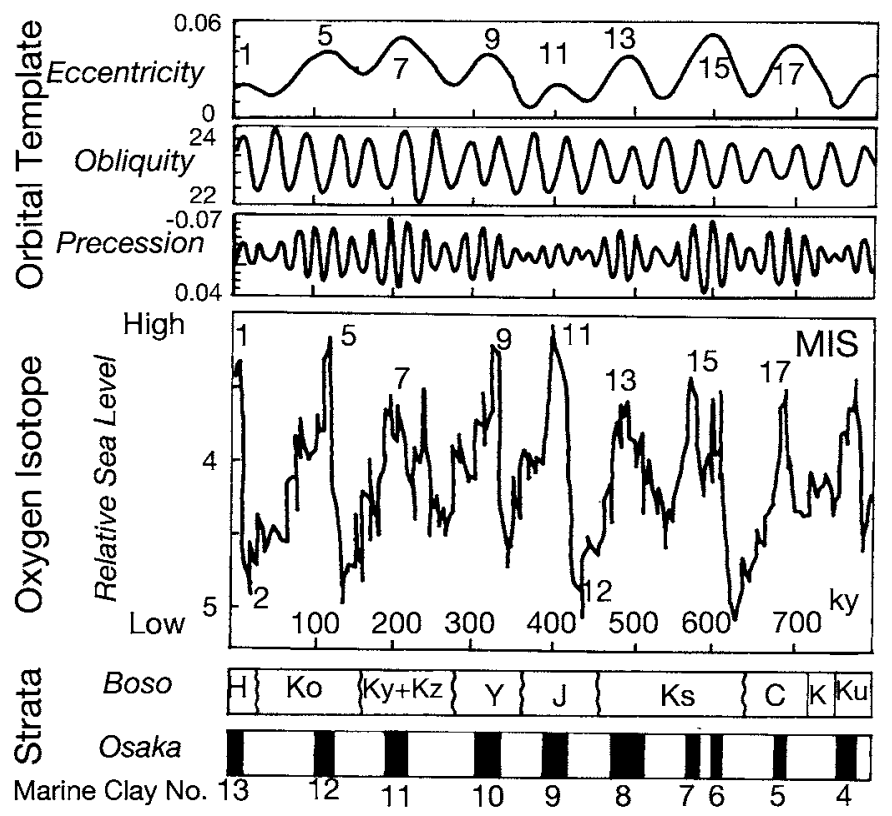

Fig. 1 Correlation of oxygen isotopic curves and orbital templates between the typical late Quaternary successions of the Boso and Osaka areas, Japan

Orbital templates are from Imbrie et al. (1984) and oxygen isotope curves of ODP Site 849 are from Mix et al. (1995). Black parts in the Osaka collum represent marine clay beds. In the Boso collum, H : Holocene, Ko : Kioroshi, Ky : Kiyokawa, Kz: Kamiizumi, Y : Yabu (Semata), J : Jizodo, Ks : Kasamori, C : Chonan, K : Kakinokidai, and Ku : Kokumoto Formations. Note the horizon of the Jizodo Formation (J) and the 9th Marine Clay Bed correlated to MIS 11 of about $400 \mathrm{ky}$ ago characterized by minimum eccentricity of the Earth's orbit and low amplitude of the precession. 
zon of the Osaka Group (Furutani, 1991). Marine diatoms are also abundant in the bed (Noguchi, 1993). Nannofossils of outer sea organisms are abundant in this bed (Okamura and Yamauchi, 1984 ; Yoshikawa, 1999). These fossil records show that the 9th Marine Clay Bed was deposited under warm climatic conditions at a time of highstand. Sugiyama and Mizuno (1991) proposed that the 9th Marine Clay Bed indicates a notably warm climate at the time of its deposition in central and southwestern Japan.

\section{Other MIS 11 deposits}

A large gravelly spit deposit (the Higashi Kanbe Gravel) is well developed in the transgressive systems tract of MIS 11 observed in the Atsumi Group on the Pacific coast of the Atsumi Peninsula (Hiroki and Masuda, 2000). This deposit might have been formed during a long period of transgression between MIS 12 (the most severe glacial period, along with MIS 6) and MIS 11, which was the first strong interglacial of the middle to late Quaternary. Droxler et al. (2003) pointed out the difficulty of determining what was a unique glacial to interglacial transition due to the extreme amplitude of the temperature curve.

Dry climatic conditions can be inferred from a long cored sequence from Lake Biwa (Hayashi et al., 1999) that correlates with MIS 11. Within this core, coarser materials in general represent interglacial deposits. However, the MIS 11 sequence of this core is characterized by finer materials, mainly silt, and is poor in hyperpycnalflow flood deposits, "hyperpycnite" (Mulder et al., 2003 ; Saito et al., 2005). This shows that the climate during MIS 11 was dry in the intra-arc area of Japan.

\section{Conclusions and future investigation}

Deposits formed during MIS 11 have different features compared to other interglacial deposits of the Japanese Islands.

It is possible that the MIS 11 of the Japanese Islands was a warmer and longer interval of highstand than elsewhere.

Further investigation of the strata of MIS 11 of the Japanese Islands is needed, and should consider not only the MIS 11 sequence, but also the transition from glacial MIS 12 (the most severe glacial, along with MIS 16) to interglacial MIS 11 (the first strong interglacial of the middle to late Quaternary).

\section{References}

Aoki, N. and Baba, K. (1971) Molluscan fossil assemblages and their stratigraphic positions in the Semata, Kamiizumi and Narita Formations of the Kisarazu-Ichihara area, Boso Peninsula. The Journal of the Geological Society of Japan, 77, 137-151. $(\mathrm{J}+\mathrm{E})$

Aoki, N. and Baba, K. (1973) Compilation of the stratigraphy and molluscan fossil assemblages of the Pleistoceene Shimosa Group, eastern part of Kwanto Plain, central Japan. The Journal of the Geological Society of Japan, 79, 453-464. (J+E)

Berger, A. and Loutre, M. (2003) Climate 400,000 years ago, a key to the Future? Droxler, A.W., Poore, R.Z. and Burckle, L.H. (eds.) Earth's climate and orbital eccentricity : The marine isotope stage 11 question : 17-26, Geophysical Monograph, 137, American Geophysical Union.

Berger, A., Loutre, M. and Crucifix, M. (2003) The earth's climate in the next hundred thousand years (100 kyr). Surveys of Geophysics, 24, 117-138.

Berger, W.H., Bickert, T., Yasuda, M.K. and Wefer, G. (1996) Reconstruction of atmospheric $\mathrm{CO}_{2}$ from icecore data and the deep-sea record of Ontong Java plateau : the Milakovitch Chron. Geologische Rundshau, 85, 466-495.

Broecker, W.S. and Stocker, T.F. (2006) The Holocene $\mathrm{CO}_{2}$ rise : Anthropogenic or natural? EOS (Transactions, American Geophysical Union), 87, 27.

Droxler, A.W., Poore, R.Z. and Burckle, L.H. (eds.) (2003) Earth's climate and orbital eccentricity : The marine isotope stage 11 question. 240p, Geophysical Monograph, 137, American Geophysical Union.

Furutani, M. (1991) Paleoclimatic and sedimentary environmental change in the Middle and Upper Pleistocene in the Osaka Basin. The Kansai Branch of Japan Society of Engineering Geology (ed.) Environment and engineering geology : 29-40, The Kansai Branch of Japan Society of Engineering Geology. (J)

Furutani, M. (1993) Subsurface of Osaka Plain. Itihara, M. (ed.) The Osaka Group : 68-86, Sogen-sha. (J)

Hayashi, T., Yamasaki, H. and Kawabe, T. (1999) Lithostratigraphy of the core sediments drilled on the Karasuma site of the east side of Lake Biwa, Kusatsu, Shiga Prefecture, central Japan. Research Report of the Lake Biwa Museum, 12, 31-60. (J+E)

Hiroki, Y. and Masuda, F. (2000) Gravelly spit deposits in a transgressive systems tract: the Pleistocene Higashikanbe Gravel, central Japan. Sedimentology, 47, 135-149.

Ikebe, N., Iwatsu, J. and Takenaka, J. (1970) Quater- 
nary geology of Osaka with special reference to land subsidence. Journal of Geosciences, Osaka City Univ., 13, 39-98.

Imbrie, J., Hays, J.D., Martinson, D.G., McIntyre, A., Mix, A.C., Morley, J. J., Pisias, N.G., Prell, W.L. and Shackleton, N. J. (1984) The orbital theory of Pleistocene climate: Support from revised chronology of the marine $\delta^{18} \mathrm{O}$ record. Berger, A.L. (ed.) Milankovitch and climate, Part 1 : 269-305, Reidel.

Itihara, M. (ed.) (1993) The Osaka Group. 340 p, Sogensha. $(\mathrm{J}+\mathrm{E})$

Kamataki, T. and Kondo, Y. (1997) Middle to Late pleisotocene shallow-marine sedimentary and faunal cycles corresponding to the orbital precession or obliquity in the Shimosa Group, Boso Peninisula, central Japan. Wang, N. and Remane, J. (eds.) Stratigraphy : 231-235, Proceedings of the 30th International Geological Congress, 11, VSP.

Kansai-Jibanjohokatuyo-Kyogikai (2002) Shin-Kansai-Jiban (New Informations for Ground Geology of Kansai District). 196 p, Osaka. (J)

Kondo, Y. (1989) Faunal condensation in early phase of glacio-eustatic sea-level rise, found in the middle to late Plaistocene Shimosa Group, Boso Peninsula, central Japan. Taira, A. and Masuda, F. (eds.) Sedimentary facies in the active plate margin : 197-212, Terra Scientific Pub. Co.

Machida, H., Arai, F. and Sugihara, S. (1980) Tephrochronolgical study on the middle Pleistocene deposits in the Kanto and Kinki districts, Japan. The Quaternary Research (Daiyonki-Kenkyu), 19, 233261. $(\mathrm{J}+\mathrm{E})$

Masuda, F. (1997a) Correlation among oxygen isotope curves, the Shimosa and Kasuza Groups and the Osaka Group : A preliminary note. The Earth Monthly, 19, 474-479. (J)

Masuda, F. (1977b) Paleotemperature and paleosalinity during a period from 400,000 to 120,000 years B.P. in the Boso Peninsula, central Japan. Annual Report, Institute of Geoscuiences, University of Tsukuba, $3,32-36$.

Masuda, F. (1977c) Measurements of paleotemperatures and paleosalinities based on the oxygen and carbon isotopic compositions, and strontium content of fossil molluscan shells. The Journal of the Geological Society of Japan, 83, 315-323. (J+E)

Masuda, F. and Ito, M. (1999) Contributions to sequence stratigraphy from the Quaternary studies in Japan. The Quaternary Research (Daiyonki-Kenkyu), 38, 184-193. $(\mathrm{J}+\mathrm{E})$

Mix, A.V., Pisas, N.G., Rugh, W., Wilson, J., Mprey, A. and Hagelberg, T.K. (1995) Benthic foraminfer stable isotope record from Site $849(0-5 \mathrm{Ma})$ : local and global climate changes. Proceeding of ODP, Science Results, 138, 371-412.

Mulder, T., Syvitski, J.P.M., Migeon, S., Faugeres, J.C. and Savoye, B. (2003) Marine hyperpycnal flows: Initiation, behavior and related deposits. A review.
Marine and Petroleum Geology, 20, 861-882.

Nishikawa, T. and Ito, M. (1997) Middle Pleistocene depositional systems in the early paleo-Tokyo Bay, Japan. The Journal of the Geological Society of Japan, 103, 1144-1161. (J+E)

Noguchi, Y. (1993) Fossil diatom of the Osaka Group. Itihara, M. (ed.) The Osaka Group : 232-246, Sogensha. $(\mathrm{J})$

O’Hara, S. (1973) Molluscan fossils from the Higashiyatsu formation. Journal of the College of Arts and Sciences, Chiba University, B-6, 67-83. (J+E)

Okamura, M. and Yamauchi, M. (1984) Detailed survey on nannofossils at the Kansai International Airport in Osaka Bay, central Japan. Geological Survey of the Submarine Strata at the Kansai International Airport in Osaka bay, Central Japan : 19-28, Report of the Calamity Science Institute. $(\mathrm{J})$

Okazaki, H. (1996) Significance of sediment supply, tectonic movement and eustatic sea-level changes to sedimentary cycles of palaeo-Tokyo Bay, analyzed from Pleistocene Shimosa Group, Japan. Journal of Natural History Museum and Institute, Chiba, 4, 1-8. $(\mathrm{J}+\mathrm{E})$

Okazaki, H., Isaji, S. and Nakazato, H. (2000) Pleistocene Gilbert-type coarse-grained delta, the Kamiizumi Formation, Shimosa Group, Japan. The Journal of the Geological Society of Japan, 106, 461-471. $(\mathrm{J}+\mathrm{E})$

Osakawan-Kibanjoho-Kenkyu-Kyogikai (2002) Bay Area-no-Jiban-to- Kennsetu (Ground and Construction in Osaka Bay area). 505 p, Committee of Osaka Bay area. ( $\mathrm{J}$ )

Saito, Y., Tamura, T. and Masuda, F. (2005) Characteristics of hyperpycnal flow and its deposits as an innovative factor for the turbidite paradigm. Journal of Geography, 114, 667-704. (J+E)

Sugiyama, Y. and Mizuno, K. (1991) A Cyclobalanopsisdominant horizon recognized in the Middle Pleistocene deposits in Southwest Japan. Programme and Abstracts, 1991 Annual Meeting of the Japan Association for Quaternary Research, 21, 84-85. (J)

Tokuhashi, S. and Kondo, Y. (1989) Sedimentary cycles and environments in the middle-late Pleistocene Shimosa Group, Boso Peninsula, central Japan. The Journal of the Geological Society of Japan, 95, 933-951. (J+E)

Yokoyama, T., Nakagawa, Y., Takemura, K. and Hayashida, A. (1980) Some problems on the middle Pleistocene deduced from sediment core samples from Lake Biwa, central Japan. The Quaternary Research (Daiyonki-Kenkyu), 19, 185-201. (J+E)

Yoshikawa, S. (1999) Function of volcanic ash layers for high accuracy dating. The Earth Monthly, 26, 201-206. (J)

(J) in Japanese, $(\mathrm{J}+\mathrm{E})$ in Japanese with English abstract. 


\title{
日本列島の地層からみた同位体ステージ 11 の古気候
}

\author{
増田富士 雄*
}

〔要旨〕

日本列島の地層の情報は, 約 40 万年前の同位体又 テージ 11 の間水期が他の間水期より温暖で長く, しか あ海面屯高かったことを示しているようだ。この時期の
古気候の復元は, この時期が現在の完新世の間水期と ミ ランコビッチ・フォーシングの要素が似ていることか ら, 将来の気候を予測する上で重要である.

キーワード : 第 9 海成粘土層 (Ma 9), 同位体ステージ 11 (MIS 11), 地蔵堂層, 間水期, 古気候 